Summer 2004

\title{
For-Profit Education Service Providers in Primary and Secondary Schooling: The Drive for and Consequences of Global Expansion
}

Amy M. Steketee

Indiana University School of Law

Follow this and additional works at: https://www.repository.law.indiana.edu/ijgls

Part of the Education Commons, and the International Law Commons

\section{Recommended Citation}

Steketee, Amy M. (2004) "For-Profit Education Service Providers in Primary and Secondary Schooling: The Drive for and Consequences of Global Expansion," Indiana Journal of Global Legal Studies: Vol. 11 : Iss. 2 , Article 5.

Available at: https://www.repository.law.indiana.edu/ijgls/vol11/iss2/5

This Note is brought to you for free and open access by the Law School Journals at Digital Repository @ Maurer Law. It has been accepted for inclusion in Indiana Journal of Global Legal Studies by an authorized editor of Digital Repository@Maurer Law. For more information, please contactrvaughan@indiana.edu.

\section{$\Psi$}

JEROME HALL LAW LIBRARY

INDIANA UNIVERSITY

Maurer School of Law
Bloomington 


\title{
For-Profit Education Service Providers in Primary and Secondary Schooling: The Drive For and Consequences of Global Expansion
}

\author{
Amy M. Stekete**
}

Innovations in technology, transportation, and communication during the twentieth century have paved the way for greater global connectedness and interdependence. ${ }^{1}$ Economic globalization ${ }^{2}$ and democratization ${ }^{3}$ have accompanied these trends toward interconnectedness. While these transformations brought vast increases in the exchange of goods, people, and information even to remote locales, this new exchange has been a boon for transnational corpora-

*J.D. Candidate, 2004, Indiana University School of Law_Bloomington; M.S., Ed., 1995, Indiana University; B.A., 1992, Indiana University. I would like to thank Professors Alfred Aman, Martha McCarthy, and Suzanne Eckes for their very thoughtful comments and recommendations on early drafts, Donald Kopis for his patience and constant encouragement, and my family for their love and support. [Editor's Note: This paper was presented at the twelfth annual global symposium, which addressed "Globalization and Education", in April 2004. The other papers presented at the symposium will make up the IJGLS Winter 2005 Issue.]

1. See generally The Globalization Reader, (Frank J. Lechner \& John Boli eds., 2000) (discussing the nuances of post-World War II global awareness); David Held et. al., Global. Transformations: Politics, Economics and Culture 2 (2000) (defining globalization as "the widening, deepening and speeding up of worldwide interconnectedness").

2. Economic globalization, for the purposes of this Note, is defined to include: the integration of markets; the alignment of values and economic mechanisms with those of capitalist systems; and the promotion and facilitation of trade, consumption, and competition. See Alex Y. Seita, Globalization and the Convergence of Values, 30 Connell INT'L L.J. 429, 430 (1997) (discussing economic globalization as the expansion of "markets for goods, services, financial capital, and intellectual property"); Nelly Stromquist, Education in a Globalized World: The Connectivity of Economic Power, Technology and Knowledge 5-7 (2002) ("Globalization results in the ability of core countries to impose new practices that bring all countries into conforming [sic] with capitalist economic systems."); S. Tamer Cavusgil, Globalization of Markets and its Impact on Domestic Institutions, I IND. J. GLobal Leg. STud. 83 (1993) ("Globalization of markets involves the growing interdependency among the economies of the world; multinational nature of sourcing, manufacturing, trading, and investment activities; increasing frequency of cross-border transactions and financing; and heightened intensity of competition among a larger number of players.").

3. Seita, supra note 2, at 429-30 ("Democracy and human rights are, for example, as much a part of globalization as are free market principles."). 
tions. ${ }^{4}$ Consequently, there is a strong impetus for transnational corporations to expand their markets by seeking a relaxation of trade barriers.

Traditionally hailed as a free, open, and community-sponsored endeavor, ${ }^{5}$ public education increasingly is permeated by corporate mechanisms and influences. ${ }^{6}$ In the United States and the United Kingdom, a growing awareness of the deficits in primary and secondary public schools, coupled with a mounting need to ready students for the global workplace, has spurred numerous reform

\section{Transnational corporations have been defined as:}

Companies or other entities established in more than one country and so linked that they may co-ordinate their operations in various ways. While one or more of these entities may be able to exercise a significant influence over the activities of others, their degree of autonomy within the enterprise may vary widely from one multinational enterprise to another. Ownership may be private, state or mixed.

Organization for Economic Co-operation and Development, The OECD Guidelines for Multinational Enterprises: 2000 Revision 17-18 (2000), available at http//www.oecd.org/ (last visited Oct. 21, 2003); see STROMQUIST, supra note 2, at 10 (since TNCs are focused "on promoting high levels of consumption, [they] promote convergence rather than divergence in the social, cultural, political, and economic dimensions of our lives").

5. See Patricia M. Harris, Student Fees in Public Schools: Defining the Scope of Education, 72 Iowa L. Rev. $1401,1402 \mathrm{n} .16$ (1987) (listing the thirty U.S. state constitutions that require public education be free); see also United Nations Declaration of the Rights of the Child, G. A. Res. 1386, GAOR, 14th Sess., Princ. 7 (1959), available at $\mathrm{http}: / \mathrm{ww}$ w.unhchr.ch/htm/menu3/b/25.htm. (last visited Mar. 2, 2004) (confirming that "[r]he child is entitled to receive education, which shall be free and compulsory, at least in the elementary stages"); Convention on the Rights of the Child, art. 28(1)(a), G.A. Res. 44/25, U.N. GAOR, 44th Sess., Supp. No. 49, at 165, U.N. Doc. A/44/736 (1989) (stating that parties to the convention recognize a right ro education and shall

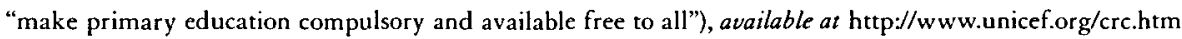
(last visited Mar. 2, 2004). Seegenerally The Republic and the School: Horace Mann on the EducaTION of Free MEN (Lawrence A. Cremlin ed., 1957) (discussing Horace Mann's efforts to promote common schools locally financed and run and open to all children regardless of social position).

6. See Stromquist, supra note 2, at 15-16:

Globalization gives particular visibility to education. It brings up the notion of the 'knowledge society,' emphasizing knowledge and skills over natural resources, material endowments, and capital. Globalization takes education systems out of the state monopoly and into the marketplace. It reorders fields of study according to the needs of the market, increasingly substituting those needs for the traditional search for truth.

See also Kurt Larsen et al., Trade in Educational Services: Trends and Emerging Issues, OECD CENTER for Education Research and Innovation 17 ("[A]lmost all countries view education, at least 
efforts, among them for-profit school management corporations. ${ }^{7}$ For-profit school management corporations have lucrative potential, but only if they operate on a large scale. Thus, there is great incentive for these for-profit education service providers to broaden their markets, while there is little reason for them to invest in cultivating communities that can self-sufficiently educate their children.

Consequently, there is a strongly supported drive to expand global trade in service industries, even in education at the primary and secondary levels. ${ }^{8}$ Specifically, the General Agreement on Trade in Services (GATS) aims to eliminate the barriers to trade in services and to promote the policies of liberalization. ${ }^{9}$ While the expansion of markets benefits the for-profit education service industry, it is likely that public education will be the loser in this zero-sum game. This Note examines the viability of for-profit education services and the indicators that encourage its expansion in trade. Further, it offers some likely implications for systems of public education if trade in primary and secondary educational services flourishes.

Part I outlines the trends in economic globalization and discusses the effects of a policy of liberalism and the proliferation of privatization and deregulationincluding service industries such as education. Part II discusses the current trends in the United States and the United Kingdom that facilitate and support the privatization and corporatization of primary and secondary education. This section also suggests ways in which globalization has encouraged the growth of this market. Part III addresses the impact that for-profit school management organizations have had on primary and secondary education in the United States and the United Kingdom. This section also considers the quality of education delivered, the effectiveness of the management system, and the degree of monetary success that for-profit school-management corporations have enjoyed.

up to a certain age, as an essential social service and provide public-funded education on a compulsory and universal basis," but there are an increasing variety of delivery systems that are private in nature.), available at http:/www.esib.org/commodification/documents/TRADEEDU.pdf (last visited Oct. 11, 2003).

7. Also referred to as for-profit education management organizations (EMOs).

8. See GATE: Ensuring Excellence in the Evolution of Global Learning, GATE News, Winter 2002 , at 3.

9. See generally General Agreement on Trade in Services, Apr. 15, 1994, Final Act Embodying the Results of the Uruguay Round of Multilateral Trade Negotiations, WTO Agreement, Annex 1B, Legal Instruments-Results of the Uruguay Round, 33 I.L.M. 1167 (1994) [hereinafter GATS] (including service sectors such as finance, healthcare, travel and tourism, education, and environmental services). 
Part IV highlights mechanisms, such as GATS, which broaden global trade in services and encourage privatized management. Finally, Part V considers the implications of for-profit education service providers on systems of public education, particularly in those countries vulnerable to market influences.

\section{Privatization and Deregulation: The Byproducts of Economic Globalization}

Economic globalization targets the opening and integration of world-wide markets. ${ }^{10}$ Alex Seita discusses three characteristics of economic globalization: it increases opportunities for trade--benefiting both sellers and buyers; it simultaneously stimulates competition and cultivates interdependency among nations; and it promotes the spread of a free market economy model because the primary proponents of globalization are industrialized nations that subscribe to free market policies. ${ }^{11}$ Today over 80 percent of the world's population lives in countries where market economies prevail. ${ }^{12}$ Consequently, the advancement of neoliberal economic policies hinges on the expansion of markets. ${ }^{13}$

Alongside market expansion come changes in the purpose and function of the state and its agencies. Neo-liberalism "calls for a less interventionist state in economic and social arenas and proposes such measures as deregulation... decentralization ... and privatization...."14 As a result, governments are as-

10. See discussion infra note 2 and accompanying text.

11. Seita, supra note 2 , at 439.

12. The World Bank, Education: Education Sector Strategy 1 (1999), available at http:// www1.worldbank.org/education/strategy.asp (last visited Oct. 11, 2003) [hereinafter Education Sector Strategy].

13. See StromQuist, supra note 2, at 25-26 ("Neoliberalism ... is an economic doctrine that sees the market as the most effective way of determining production and satisfying people's needs.").

14. Id. at 6. Stromquist defines these measures as follows:

1. Deregulation: Favors a general withdrawal of the state from control or oversight over economic and financial transactions and removal of all government/public interventions that might affect the free functioning of the markets (removal of price controls on goods and services, elimination of public subsidies, and so on).

2. Privatization: Requires an increased role of the private sector in providing goods and services, prioritizing full cost recovery and efficiency.

3. Liberalization: Relinquishes domestic production over most sectors of the economy (including trade and finance), eases control of foreign investment and capital, 
suming greater roles in facilitating and regulating economic activity rather than directly producing and delivering goods and services. ${ }^{15}$ In the race for efficiency and economic returns, countries that once clung to centralized systems of governance are now willing to permit privatization and deregulation. ${ }^{16}$ In fact, the Secretariat of the World Trade Organization suggests the liberalization of international trade is "predicated on an economic environment in which privatization and deregulation are essential prerequisites." ${ }^{17}$

Encouraging the development of varied new products and services, privatization has invited the dominance of non-national institutions, including transnational corporations. ${ }^{18}$ Inherently, the first concern of transnational corporations is to generate profits for shareholders; addressing the needs and preserving the values of developing countries is generally a lower priority. ${ }^{19}$ Financial incentives that encourage expansion and easy access to technology allow transnational corporations to infiltrate and control the market. ${ }^{20}$ Since neo-liberalism promotes commodification of all goods and services, there are few areas immune to marketization..$^{21}$ Even areas that have traditionally been considered public services and goods are filtering into the marketplace. ${ }^{22}$ Consequently, governments promoting neo-liberal policies are pressured to reduce state regulations that restrain private influence and to facilitate the transforma-

reduces trade tariffs and duties, and permits foreign companies to own key enterprises such as national banks .... According to the liberalization principle, the cost of products and services is no longer set by public or social criteria. Since liberalization applies to all sectors (with the exception of national defense), it affects traditional social sectors, such as education ... and basic services.

Id. at 26.

15. See Education Sector Strategy, supra note 12, at 2.

16. See Seita, supra note 2, at 443.

17. The WTO and the Millennium Round: What is at Stake for Public Education/Common Concerns for Workers in Education and the Public Sector, Education International and Public Services International Joint Publication, available at http://www.ei-ie.org/pub/english/epbeipsiwto.html (last visited Feb. 26, 2004).

18. See Stromquist, supra note 2 , at 6 .

19. See id.

20. See id. at 10.

21. See Larry Kuehn, Presentation to IDEA conference in Quito, Ecuador, Responding to Globalization of Education in the Americas-Strategies to Support Public Education 2 (1999), at http:// www.bctf.bc.ca/social/globalization/responding.html (last visited Feb. 26, 2004).

22. See id. See generally Jerry Ellig and Kenneth Kelly, Competition and Quality in Deregulated Industries: Lessons for the Education Debate, 6 Tex. Rev. L. \& PoL. 335 (2002) (highlighting advantages and disadvantages of deregulation in traditional public service sectors). 
tion of social goods-including public health services and education-into commodities. ${ }^{23}$

Education is important in the expansion of neo-liberal economic policies for a number of reasons. First, the education industry is one of the last great frontiers for for-profit ventures. ${ }^{24}$ Education International, a world-wide organization of education personnel that aims to promote equality in education and protect the rights of teachers and vulnerable groups, ${ }^{25}$ suggests that annual global public spending on education exceeds one trillion dollars. ${ }^{26}$ The United States alone exports well over $\$ 10$ billion in education services. ${ }^{27}$ Consequently, the size of the market-both in terms of number of participants and the potential for economic returns-makes education services an alluring industry. ${ }^{28}$

Second, education plays a unique role in preparing students to become participants in global market economies, thereby ensuring the further entrench-

23. Mark K. Smith, Globalization and the Incorporation of Education, THE ENCYCLOPEDIA of INFORMal Educ. 2-3 (2002), at http://www.infed.org/ (last updated Oct. 22, 2002) (last visited Feb. 26, 2004).

24. In preparation for the 2001 World Education Market, Eduventures-a corporate group supporting the growth of the education industry-was asked to identify reasons for education industries to "go global." Among these are: "developing new revenue streams, escaping home market economic stagnation, deepening the value of product offerings via international partnerships, leveraging technology leadership in a new market, sustaining a competitive advantage vis-à-vis other global or potentially global players, and creating scale to satisfy investor demands for fast growth." Peter Stokes, White Paper: A Global Education Market? Global Businesses Building Local Markets, May 2001, at 2, 4, available at http://www.eduventures.com/ (last visited Feb. 27, 2004).

25. See Education International, at http://www.ei-ie.org/ (last visited Feb. 27, 2004).

26. See Elie Jouen et al., Questions for Debate, The WTO and the Millennium Round: What is at Stake for Public Education, Education International Publication, May 1999, at 1, available at http://www.ei-ie.org/ (last visited Feb. 27, 2004). But see Harry Anthony Patrinos, Draft, Promoting Access to Post-Secondary Education: Meeting the Global Demand, World Bank (Apr. 23, 2002) (estimating global household spending on public and private education to top $\$ 2$ trillion), available at http://www.oecd.org/ (last visited Feb. 27, 2004).

27. See Press Release, Office of the United States Trade Representative, U.S. Proposals for Liberalizing Trade in Services: Executive Summary 5 (July 1, 2002) (receipts from incoming services total over $\$ 10$ billion a year and receipts from training services total $\$ 400$ million a year), available at http:/www.ustr.gov/ (last visited Feb. 27, 2004); World Trade Organization: Council for Trade in Services, Education Services, Background Note by the Secretariat, S/C/W/49, at para. 23 (Sept. 23, 1998), available at http://docsonline.wto.org/ (last visited Feb. 27, 2004) [hereinafter Background Note] (estimating 1996 U.S. exports of consumption abroad at $\$ 7$ million and noting that the United States, France, Germany, and the United Kingdom are the leading exporters of education services).

28. Kuehn, supra note 21, at 2-3. 
ment of neo-liberal economic policies. Business leaders and politicians look to primary and secondary education providers to produce a well-trained and competitive labor force. Thus, primary and secondary schools are increasingly concerned with teaching technical skills essential to the production and transfer of goods in addition to promoting the social and academic aspects of global awareness and interconnectedness. ${ }^{29}$ Further, from very early ages children are accustomed to market influences in schools. ${ }^{30}$ This exposure to commercialization in schools, together with academic emphasis on preparing students for participation in the global workforce, indoctrinates children with the values of neoliberalism and facilitates its spread.

One of the primary effects of economic globalization (in a broad context and in the narrower context of educational services) is the appearance of private influence in operations that are traditionally state controlled. Private involvement in the provision of education services can be considered privatization. ${ }^{31}$ This shift from government to private control can include delivery of the service and the policy-making structures that determine how the service is offered. ${ }^{32}$ For years, schools in the United States have outsourced services for bus transportation, building construction, and food preparation. ${ }^{33}$ Over time, this outsourcing has narrowed to include contracts for the exclusive sale of food and drinks, contracts for athletic uniforms with sponsor logos, and contracts for free communications equipment in exchange for advertising time. ${ }^{34}$ However, only recently have public school systems contracted with for-profit (and non-profit) private

29. See Stromquist, supra note 2, at 38; see also School-to-Work Opportunities Act of 1994, 20 U.S.C. $\S 6101(2004)$.

30. For example, students in over 12,000 middle and high schools across the United States regularly watch two minutes of advertising during the school day as part of an agreement between the school districts and Channel One. In exchange for televisions and other technical equipment, schools agree to broadcast Channel One programming. See Alex Molnar, Sponsored Schools and Commercialized Classrooms: Schoolhouse Commercializing Trends in the 1990s, CTR. For THE Analysis of Commercialism in Educ., Aug. 1998, at 22, available at http://www.asu.edu/ (last visited Feb. 27, 2004).

31. See Samuel Flam \& William G. Keane, Public Schools/Private Enterprise: What You Should Know and Do About Privatization 23 (1997) (quoting Cliff Atherton \& Duane Windsor, Privatization of Urban Public Services, in Entrepreneurship and the Privatizing of GovernMENT 82 (Calvin A. Kent ed., 1987)).

32. Flam \& Keane, supra note 31 , at 23.

33. Id. at 28.

34. See Stromquist, supra note 2 , at 45. 
providers for instructional services and management systems. ${ }^{35}$ Education management organizations (EMOs) run schools (and sometimes even entire school districts) by managing a school's every operational detail, including the hiring of teachers, selection of a curriculum, and management of classrooms. ${ }^{36}$ While the groundwork has been in place for a long time, these management corporations complete the process of transforming what is considered a "public service into a source for private profit." ${ }^{37}$

Another result of the spread of economic globalization is an altered role for the state in delivering public educational services. In both the United States and the United Kingdom, there have been recent, wide-sweeping legislative and administrative reforms aimed at deregulating public education. These measures include permitting private providers greater access to struggling public schools, ${ }^{38}$ reducing governmental oversight of public schools that meet steep accountability standards, ${ }^{39}$ promoting greater parental choice in public schooling options, ${ }^{40}$ and encouraging competition among various forms of schooling. ${ }^{41}$

35. Id. at 35-41. This recent openness to privatization in schools has been spurred by reports of deficiencies in the public school system.

36. See Barbara Miner, For-Profits Target Education, in Education, Inc.: Turning Learning into a Business 133 (Alfie Kohn \& Patrick Shannon eds., 2002).

37. $I d$.

38. For example, the legislature in Pennsylvania changed code language to allow districts to contract for teaching and management services. This deregulatory act paved the way for the school district in Philadelphia to contract with Edison Schools. See 24 Pa. Cons. Stat. § 6-696(i)(2) (1998). In the United Kingdom, the 2002 Education Act allows school governing bodies to set themselves up as companies and permits the formation of "federations" of schools. Consequently, schools are free to contract with private service providers. This Act provides the deregulatory framework for businesses to infiltrate schools. See Education Act, 2002, c. 32 (Eng.).

39. See No Child Left Behind, 20 U.S.C. $\$ 6311$ (2001) (requiring schools that repeatedly fail to meet adequate yearly progress measures to allow parents the choice to transfer their student to a different school and to contract with private supplemental service providers to offer remediation). Virtually all states have enacted state corollaries that set forth specific standards for achievement. See, e.g., Pennsylvania's Educational Empowerment Act, 24 Pa. Cons. Stat. § 17-1701-16 (2000).

40. See Center for Education Reform, Charter Schools (listing forty-one states that have passed charter school legislation as of January 2003), at http://www.edreform.com/ (last visited Jan. 15, 2004); see also Brad Colwell \& Brian Schwartz, Implications for Public Schools: Legal Aspects of Home Schools, 173 West's Ed. L. RPTr. 381, 393-95 (2003) (examining the variety in home school laws across the 50 states and discussing the recent revival of this educational option).

41. See generally Zelman v. Simmons-Harris, 536 U.S. 639 (2002) (upholding Cleveland voucher program against an Establishment Clause challenge); Privatizing Education: Can the Marketplace Deliver Choice, Efficiency, Equity, and Social Cohesion? (Henry M. Levin ed., 
While many believe that deregulation will stimulate competition and catalyze improvements in the quality of education and the performance of students, these reforms are likely to have implications for values that drive the provision of education as a public good..$^{42}$ Greater autonomy in parental school choice brings many benefits, but in the exchange children may lose out on the advantages of a pluralistic education directed by common civic goals. Moreover, as parents exercise their choice to direct their children to alternative education providers, public funds are thinned even as they are dispersed across a variety of public school options. As a result, public schools will struggle to provide adequate services. As more authority for public education is delegated to parents and private providers, the state's role in public education policy making is dramatically redefined.

\section{The Expanding Market Influence on Public Education in the United States and the United Kingdom}

In the last part of the twentieth century, school leaders in western countries, specifically in the United States and the United Kingdom, have been encouraged to adopt a managerial approach to education. ${ }^{43}$ Trained on a managerial model, these leaders approach educational challenges as opportunities to produce specified outcomes in student achievement. ${ }^{44}$ While targeted goals and reliable methods are critical to improvements in education, they are also conducive to

2001) (discussing implementation issues, international dimensions, evaluation designs, and various stakeholder perspectives on vouchers and charter schools); John F. Witte, The Market Approach to Education: An Analysis of America's First Voucher Program (2000) (discussing historical background, politics, and an evaluation of the Milwaukee Voucher Program).

42. See generally Jerry Ellig \& Kenneth Kelly, Competition and Quality in Deregulated Industries: Lessons for Education, 6 Tex. Rev. L. \& PoL. 335 (2002) (discussing the opposing viewpoints in the school choice debate-either "choice will elevate the quality of education as a result of competition" or "choice will destroy public education as money and motivated students leave the system").

43. Smith, supra note 23 , at 4 . This rise in managerialism has been considered a "manifestation at the educational level of economic tendencies promoted by neoliberalism." STromQuist, supra note 2, at 40. See generally Martha McCarthy, The Evolution of Education Leadership Preparation Programs, in Handbook of Research on Educational Administration 119-39 (J. Murphy \& K.S. Louis eds., 1999) (discussing trends in school leadership preparation programs including the most recent movement away from managerialism); Tony Bush \& Derek Glover, National College for School Leadership, School Leadership: Concepts and Evidence (Spring 2003) (discussing various models for school leadership in the United Kingdom and the United States), available at http:// www.ncsl.org.uk/ (last visited Jan. 20, 2004).

44. Smith, supra note 23 , at 4. 
enterprising efforts that take a "cookie-cutter" ${ }^{45}$ approach to student learning. ${ }^{46}$ Consequently, common educational challenges, together with a drive for greater efficiency, have ushered in a new standardization in education. There is great pressure for school systems to adopt uniform curricula, assessment measures, teaching methods, and even school management models. ${ }^{47}$ For example, in the early 1990s the United Kingdom adopted a national curriculum ${ }^{48}$ Similarly, as the result of a standards-based accountability movement in the United States, most states have now adopted specific targets for student learning. Although it is possible to implement a standardized system and still view public education as a state sponsored endeavor, in many cases education is taking on the semblance of a "private, rather than a public, good." ${ }^{\text {,49 }}$ Outcome-based goals together with assembly line standardization seem to be a natural fit with private and market influences. Furthermore, outcries for greater school accountability and recent federal legislation imposing rigid consequences on schools that fail to meet adequate yearly progress goal $s^{50}$ contribute to an educational landscape vulnerable to private sector influences, such as for-profit school management firms.

At the same time, education in the United States alone is a lucrative business. ${ }^{51}$ The largest portion of the education market, $\mathrm{K}-12$ schooling, takes in approximately $\$ 405.8$ billion per year-most of which comes from public sources. ${ }^{52}$

45. This term is used by Kathleen Conn in her article, For-Profit School Management Corporations: Serving the Wrong Master, 31 J.L. \& Educ. 129, 145 (2002).

46. See Smith, supra note 23.

47. See id.

48. Id. See also National Curriculum Online at http://www.nc.uk.net/ (last visited Oct. 11,2003).

49. Smith, supra note 23. It is interesting to note that public school administrators are also taking on greater roles in marketing their schools. In the United States, United Kingdom, and Israel, it is increasingly common for administrators to publish materials describing and promoting their educational programs, extracurricular activities, specialized curricula, libraries, and teaching staff. See Stromquist, supra note 2, at 44.

50. See No Child Left Behind Act of 2001, 20 U.S.C. $§ 6311$ et. seq. (2001).

51. See Kathleen Conn, When School Management Companies Fail: Righting Education Wrongs, 31 J.L. \& Educ. 245, 251 (2002); see also Henry A. Giroux, Stealing Innocence: Youth, Corporate Power, and the Politics of Culture 85 (2000) (stating that the for-profit education market represented around $\$ 600$ billion in revenue for corporate interests).

52. Lena M. McDowell \& Frank Johnson, Nat'l Ctr. For Educ. Statistics, Early Estimates of Public Elementary and Secondary Education Statistics: School Year 2001-02, Educ. Stat. Q., at 2, April 2002, available at http:/nces.ed.gov/("Revenues for public elementary and secondary education in FY2001 are estimated to be $\$ 386.5$ billion, and they are expected to rise to approximately $\$ 405.8$ billion in FY2002; [c]urrent expenditures ... for FY2002 are estimated to be $\$ 358.0$ billion."). 
Since public schools annually spend about $\$ 80$ billion a year on non-educational purchases alone, ${ }^{53}$ it is not surprising that there is an abundance of for-profit firms interested in providing both educational and non-educational goods and services. In addition to offering curricular materials, supplies, and equipment, many for-profit firms offer direct services, such as vocational training, foreign language instruction, and remedial education. For example, Sylvan Learning Center has created a niche in the education market by offering remedial instruction and tutoring services for over ten years. ${ }^{54}$ Additionally, there has been a recent emergence of education management organizations (EMOs) that assume all operational and decision-making responsibilities but not ownership of the public school facilities. In the course of seeking contracts with public school districts, these for-profit firms market the goals and successes of their institution and "sell 'the learning experience." 55 In a sales pitch, educational philosophies and methodologies are reduced to sound bites; school leaders and parents become consumers; and students become the products by which their services are measured. ${ }^{56}$ While successful students are the most strategic marketing tool, these firms, by nature, are most interested in the bottom line: expanding their market to satisfy investors. ${ }^{57}$

Though established in 1992, Edison Schools did not start its school management program until 1996 and has since become the most prominent for-profit management corporation in the United States. ${ }^{58}$ Edison has established a model of school management that is based on ten guiding principles, ${ }^{59}$ which provide

53. Conn, supra note 51 , at 251.

54. Sylvan has contracts with at least five large public school districts in the United States to provide on-site assistance for students who require supplemental education services. Generally, funding for such services come from federal funds provided through Title I of the Elementary and Secondary Education Act of 1965 (reauthorized as No Child Left Behind Act of 2001, 20 U.S.C. $\S 6310(2002))$.

55. See Smith, supra note 23.

56. See id.

57. See Edison Schools, Company Profile, available at http:/www.edisonschools.com/ (last visited Oct. 11, 2003); Nord Anglia, at http:/www.nordanglia.com/(last visited Oct. 11, 2003).

58. See Jay Mathews, The Philadelphia Experiment, Educ. Next, Winter 2003, at 52.

59. These fundamentals include:

1) Schools organized for every student's success; 2) A better use of time; 3) A rich and challenging curriculum; 4) Teaching methods that motivate; 5) Assessments that provide accountability; 6) A professional environment for teachers; 7) Technology for an information age; 8) A partnership with families; 9) Schools tailored to the community; and 10) The advantages of system and scale. 
the framework for management in each of its public school franchises. Edison schools employ a "Success For All" method of teaching reading (in which students are placed in small groups and tested frequently), longer school days and school years, systems that test a student's progress monthly, and rigorous evaluations of teaching and supervisory staff. ${ }^{60}$ These methods of instruction and management are the hallmarks of the Edison system. As of the 2002-03 school year, Edison ran 150 schools (including the some twenty schools recently acquired in the Philadelphia contract ${ }^{61}$ ) and served over 132,000 students across the country. ${ }^{62}$ By running its schools from a central administrative hub, Edison aims to save money and spread technology. ${ }^{63}$ As a result, Edison's formula is especially appealing to under-resourced, often distressed, inner-city schools. ${ }^{64}$

Recently, Edison expanded its market overseas. In January 2003, Edison entered a partnership with Essex County Learning Services (the second largest school district in the United Kingdom) to market an educational design for schools throughout Essex County ${ }^{65}$ As Edison's first international foray, these schools opened in the fall of $2003 .{ }^{66}$

Edison Schools, Ten Fundamentals Behind Edison's School Design, available at http://www. edisonschools.com/ (last visited Oct. 11, 2003).

60. Mathews, supra note 58, at 53.

61. Id. at 51; see also Pa. Judge Says Edison Can Have Role in Philadelphia Schools, Scr. L. News, Jan. 4, 2002, at 3 .

62. Edison Schools, Company Profile, available at http://www.edisonschools.com/ (last visited Oct. 11, 2003); see also Edison Schools, Fifth Annual Report on School Performance 2001-2002, at 4, available at http://www.edisonschools.com/ (last visited Oct. 24, 2003) [hereinafter Edison Annual Report].

63. See Matthews, supra note 58, at 53.

64. Id. For example, when the Washington, D.C. school district was facing $\$ 500$ million in deferred maintenance needs in 1995 , an EMO promised $\$ 850,000$ to $\$ 1$ million in improvements that

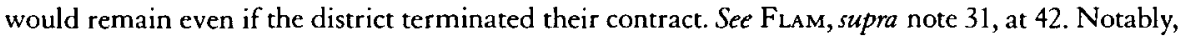
Edison has recently been asked to manage a number of schools that have been identified as failing under the No Child Left Behind framework. See Edison Annual Report, supra note 62, at 5, 26-27. Apart from its school management operations, Edison has developed programs for the provision of summer school, after school, and other "supplemental services" (i.e. remediation and tutoring services). See id. at 9-10. Edison is prepared to market these services to school districts required to provide "supplemental services" as a consequence for failing to meet annual yearly progress goals mandated by the No Child Left Behind Act. Over the next few years, Edison's revenues are likely to increase as more and more public schools become obligated to offer "supplemental services" and are identified for restructuring.

65. See Edison Annual Report, supra note 62, at 9.

66. See id. 
While Edison is the forerunner in education management in the United States, and is one of the few management firms that has enjoyed longevity, there are others. For example, in 2001 Beacon Education Management ${ }^{67}$ merged with Chancellor Academies, Inc. ${ }^{68}$ to create Chancellor Beacon Academies, the second largest for-profit management firm in the United States. ${ }^{69}$ This education management organization provides a variety of services from consulting to entire school management for over 19,000 students, many of whom attend public schools. ${ }^{70}$ In September 2000, Nobel Learning Communities, Inc., another leading for-profit school management firm that builds and operates its private schools in an identical fashion across locales, partnered with South Ocean Development Corporation, the largest education provider in the People's Republic of China." Together they market private "international schools" in Beijing and elsewhere. ${ }^{72}$

The lucrative business potential of for-profit school management systems has also infiltrated education in the United Kingdom. In Britain, education management organizations have been in operation in one form or another for at least thirty years. ${ }^{73}$ Until recently however, U.K. service providers have offered only indirect services, such as property management, accounting, and payroll operations. ${ }^{74}$ The British School Standards and Framework Act, enacted in

67. Beacon Education Management was founded by businessmen John Eason and William DeLoache in 1992. Under its former name, Alternative Public Schools, Beacon contracted with a Pennsylvania district and after numerous suits in response to teacher termination a Pennsylvania judge held that it was illegal for a for-profit corporation to control a public school. This ruling has since been superseded by Pennsylvania Act 46. See 1998 Pa. Legis. Serv. 46 (West) (codified as PA. Stat. Ann. tit. 24 §6-696 (West 2003)).

68. Chancellor Academies, Inc. was founded by a former Superintendent of Miami-Dade County School District.

69. See Chancellor Beacon Academies, About Us, available at http://www.chancelloracademies .com/ (last visited Oct. 11, 2003); see also Gerald W. Bracey, What You Should Know About the War Against America's Public Schools 117 (2003).

70. See Bracey, supra note 69, at 117-18.

71. See id. at 121; see also Peter Stokes, A Global Education Market? Global Businesses Building Local Markets, White PAPER, May 2001, available at http:/www.eduventures.com/ Global_Education_Market.pdf (last visited Oct. 11, 2003). See generally Mike Neihouser, Nobel Learning Communities, Inc., Nov. 21, 2000 (providing history and financial background on Nobel), available at http://www.diplomaticplanet.net/ (last visited Oct. 11, 2003).

72. See BraceY, supra note 69 , at 121.

73. Oliver Burkeman, Next Stop, Schools, Guardian Undimited, June 26, 2001, available at http://politics.guardian.co.uk/ (last visited Oct. 11, 2003).

74. See id. 
1998, gave local education authorities an opportunity to contract for education services and management if the Secretary of State determines that the local authority has failed to adequately perform these functions. ${ }^{75}$ To facilitate the process of outsourcing, the Department for Education and Employment in 1999 prepared a list of approved providers. ${ }^{76}$ Consequently, in the past few years numerous private companies have entered multi-million pound contracts with local education authorities to set student achievement goals and manage everything from teacher recruitment to classroom maintenance. ${ }^{77}$ By 2001 , twenty local education authorities had contracted with these education management organizations. ${ }^{78}$ For these companies, education is a low-return business. ${ }^{79}$ Despite the fact that the contracts (with local education agencies) are often for eight years, returns seldom exceed five percent. ${ }^{80}$ Like for-profit management corporations in the United States, the only way for these companies to increase their profits is to expand their markets. ${ }^{81}$

Nord Anglia, which was founded in the 1970s by former teacher Kevin McNeary, is the U.K. leader in for-profit school management. ${ }^{82}$ Providing services to more than half of the local education agencies in the United Kingdom (and with established relationships in over 2,600 schools), ${ }^{83}$ Nord Anglia was worth $£ 32$ million in $2001 .{ }^{84}$ Originally a developer of a private school model, Nord Anglia

75. School Standards and Framework Act, 1998, c. 31, §8 (Eng.).

76. See Education and Employment Committee, Seventh Report, 2000, Cm. 5 (Legislative Basis for Intervention by Private Sector Organizations), available at http://www.parliament.thestationery-office.co.uk/ (last visited Nov. 28, 2003).

77. See Nick Mathiason, Can Schools Survive Commercial Drive?, Guardian Unlimited, Feb. 11, 2001 available at http//observer.guardian.co.uk/ (last visited Oct. 11, 2003).

78. See id.

79. Id.

80. Id.

81. Id. This is already happening in higher education in the United Kingdom. For example, U.K. University Schools of Education supplement their income by providing consultancy services to countries such as Chile, Poland, and Romania. See Glenn Rikowski, Paper Prepared for the House of Lords Select Committee on Economic Affairs-Inquiry into the Global Economy $\$ 3.6$ (Jan. 22, 2002), at http://int-protest-action.tripod.com/id261.htm (last visited Nov. 30, 2003).

82. See Mathiason, supra note 77.

83. Steven Frazer, Nord Anglia, Hemscott Invest., Sept. 5, 2003, at http://www. hemscott .co.uk/ (last visited Oct. 23, 2003).

84. See Mathiason, supra note 77; see also Nord Anglia Education PLC, Annual Report and Accounts for the Year Ended 31st August 2001, at http:/www.nordanglia.com/html/nord2001.pdf (last visited Oct. 23, 2003). Note: the British pound conversion is roughly $£ 1.6$ to $\$ 1$ American. 
has expanded its market to the public sector. ${ }^{85}$ Today, it advertises that one of its top priorities is to develop partnerships with local education authorities to provide leadership, management, personnel, and curricular support services. ${ }^{86}$ Moreover, Nord Anglia manages a number of contracts on behalf of the Department for Education and Skills in the United Kingdom and inspects state-funded schools on behalf of the Office for Standards in Education to ensure compliance with the Education Act of $1992 .{ }^{87}$ In 2001, Nord Anglia was awarded a highly publicized contract with the low-performing Abbeylands public school in Surrey. ${ }^{88}$ Advertising themselves as a "one-stop service" for high quality schools, Nord Anglia has targeted partnerships with many more schools across the United Kingdom and has even developed a number of independent schools outside the United Kingdom that provide education aligned with the British national curriculum. ${ }^{89}$ Some of the overseas sites include Berlin, Bratislava, Ho Chi Min City, Moscow, Prague, and Warsaw. ${ }^{90}$

Another leading education management corporation in the United Kingdom is W.S. Atkins, which has established a reputation as one of the world's most prominent providers of consulting and support services. ${ }^{91}$ W.S. Atkins has experience consulting in the private and public sector in a variety of marketsincluding health, transportation, power, and defense-and has recently ventured into education. ${ }^{92}$ Atkins has won a number of contracts to manage schools in the United Kingdom under which it will provide education services ranging from maintaining buildings and hiring teachers to selecting and purchasing instructional materials. ${ }^{93}$ Accommodating more than 20,000 pupils, contracts with these schools have generated revenue of approximately $£ 270$ million. ${ }^{94}$ W.S. Atkins

85. See Nord Anglia Education PLC, About the Group, at http://www.nordanglia.com/ (last visited Oct. 23, 2003).

86. Nord Anglia Education PLC, Local Education Authority Contracts, at http://www.nordanglia.com/ (last visited Oct. 11, 2003).

87. See Nord Anglia Education PLC, DFES Contracts, at http://www.nordanglia.com/ (last visited Oct. 11, 2003).

88. See Nord Anglia Education PLC, Abbeylands School, Survey, at http://www.nordanglia .com/ (last visited Oct. 11, 2003).

89. See id.

90. Nord Anglia Education PLC, Overseas Schools, at http://www/nordanglia.com/ (last visited Oct. 11, 2003).

91. Atkins Global at http://www.wsatkins.com/wsainternet/(last visited Oct. 11, 2003).

92. Id.

93. See Global, supra note 77.

94. See Atkins Education, supra note 91. 
has also partnered with Innisfree (another management corporation) to establish NewSchools, a joint venture to design, build, finance, and operate schools in the local public education authorities. ${ }^{95}$ Presently, almost 13,000 children in London, Kent, Wales, and Cornwall attend schools that are run by NewSchools. ${ }^{96}$ Each contract generates revenues varying from $£ 12$ to $£ 100$ million. ${ }^{97}$ In 2001 , Atkins entered the largest education contract to date in the United Kingdom by partnering with Southwark schools. ${ }^{98}$ The management firm took responsibility for school improvement, pupil support services, and the repair and maintenance of school buildings. ${ }^{99}$ However, in March 2003, amidst criticism and concerns about profitability, Atkins terminated their contract three years early. ${ }^{100}$

In addition to the deregulation that has permitted for-profit school management organizations to infiltrate public education, government in the United Kingdom has taken many affirmative steps to open the doors to corporate and market influence. For instance, in an effort to raise standards among schools in the United Kingdom, the government has created Educational Action Zones. ${ }^{101}$ These zones, which are typically located in areas marked by underachievement and economic disadvantage, include two or three secondary schools and their

95. NewSchools, at http:/www.newschools.co.uk/ (last visited Oct. 11, 2003). This partnership is supported by the Private Finance Initiative (PFI) and Public Private Partnerships (PPPs), initiatives of the Conservative Government (in the 1990s) and the current Labour Government, respectively. These PPI/PPP projects involve contracting with the private sector to design, build, finance, and operate public facilities. While the private sector initially finances construction of the facilities, the state slowly, but regularly, repays the private contractor for the use of the buildings and the services provided. Since payments are classified as revenue, they do not count against public borrowing and do not begin until the construction is completed. See What are Public Private Partnerships?, BBC News, February 12, 2003, available at http://www.news.bbc.co.uk/ (last visited Oct. 24, 2003).

96. NewSchools, supra note 95.

97. Id.

98. See id.

99. Id.

100. See Terry Macalister, Union Anger as Atkins Walks Out on $1100 \mathrm{~m}$ Classroom Contract, Guardian Unlimited, Apr. 3, 2003, available at http://www.guardian.co.uk/ (last visited Jan. 20, 2004). Southwark schools have since selected Cambridge Education Associates (CEA) to service the 35,000 students in their schools. CEA provides education consultancy and management services and is part of the Mott MacDonald Group, which is a leader in transnational consulting. See Southwark Council, Southwark Appoints CEA as Interim Contractor, July 24, 2003, at http:// www.southwark.gov.uk/ (last visited Jan. 20, 2004).

101. Education Action Zones are an initiative of the Labour Government and were established by the School Standards and Framework Act in September 1998. 
feeder primary schools. ${ }^{102}$ Each zone is supported by partnerships among businesses, parents, schools, and the local education authorities. ${ }^{103}$ Initially, a zone receives a grant from the Department for Education and Skills ranging between $£ 250,000$ and $£ 1$ million and is eligible to receive matching grants based upon funds generated by business partners. ${ }^{104}$ As an incentive to innovate and reform, zones are permitted to reject the national curriculum and make local decisions regarding teacher compensation and conditions. ${ }^{105}$ The Lambeth Zone, which has made significant efforts to promote literacy, out-of-school learning, and the use of instructional technology across the community, is supported by Shell Corporation. ${ }^{106}$ Thus, in a variety of capacities corporate mechanisms have been welcomed to the table of discourse on education reform and have taken leading roles in effecting change.

In terms of moving towards privatization of primary and secondary education markets, the United Kingdom is leading the way. ${ }^{107}$ A significant number of these companies, including W.S. Atkins and Nord Anglia, that have moved into the education business in recent years have been transnational corporations that depend on an expanding market. Clearly, these corporations have seen the lucrative nature of a deregulated education sector. ${ }^{108}$

102. Education Action Zones, at http $/ /$ www.eazas.org.uk/eazas/abouteaz.htm (last visited Oct. 11, 2003).

103. Id.

104. See generally Department for Education and Skills, Education Action Zone, at http:// www.standards.dfes.gov.uk/eaz/ (last visited Oct. 23, 2004).

105. See Department for Education and Skills, EAZ HandBook, ch. 3, 7 (June 2002), available at http://www.standards.dfes.gov.uk/ (last visited Oct. 23, 2004).

106. See Statutory Instrument 1998 No. 1954, The CfBt/Lambeth Education Action Zone Order (Aug. 1998), available at http://www.hmso.gov.uk/ (last visited Oct. 23, 2003); see also CfBT/Lambeth Education Action Zone, at lambeth.gov.uk/education (last visited Oct. 23, 2003).

107. Note, though, that in the area of privatization of higher education, Australia has set the standard. See generally Carolyn Allport, Transnational Education and GATS-An Autralian Perspective, Presentation to EI Conference on Higher Education, Montreal (Mar. 13-15, 2002) (identifying Australian models of transnational education).

108. Peter Frase \& Brendan O'Sullivan, 180/Movement for Democracy and Education: The Future of Education Under the WTO, available at http://www.corporations.org/democracy/wtoed.html (last visited Oct. 11, 2003). 


\section{Measuring the Success of For-Profit School Management Corporations in the United States and United Kingdom}

The success of these for-profit management firms is difficult to ascertain for a variety of reasons. First, there are so many extraneous variables impacting educational outcomes that attributing success or failure to one specific source can hardly ever be done with certainty. For example, many of the school districts with which management corporations contract are in such political, economic, and administrative turmoil that odds of immediate success are stacked against them from the beginning. In many cases, it takes Herculean efforts to merely counterbalance a culture of failure, much less bring about decisive and sudden improvement. Additionally, many school management firms face not only weak infrastructures, but outright resistance from teacher unions and public groups opposed to outside intervention. This resistance certainly impacts a school's potential. Finally, schools of choice, such as those with for-profit management, often draw particularly motivated parents, who are more likely to contribute to their children's educational success regardless of the institutional settinganother factor which can skew the calculus of success measurement. Second, and as a corollary to the first reason, there are, in many cases, few schools which can be used as reasonable comparators to those schools managed by for-profit firms. Third, since many contracts between for-profit firms and public schools have been cut short, driving numerous firms to bankruptcy, it is a challenge to gather and meaningfully assess long-term impact data. ${ }^{109}$ With such slight longevity it is difficult (and perhaps unfair) to draw any definitive conclusions about the potential success of for-profit management firms. Fourth, the definitional boundaries of what constitutes a quality education make measuring success a tenuous goal. Before the recent standards movement, localities had greater control over educational goals and values to impart. As a result, educational suc-

109. For example, Education Alternatives, Inc. (EAI) secured contracts in the 1990s with Baltimore pubic schools, Hartford public schools, and the School Board of Dade County, Florida. But, in each locale the contract was either cancelled early or not renewed. After these failures EAI renamed itself TesseracT, and attempted contracts with a number of cities in Arizona and on the west coast. But in 2000 TesseracT filed for Chapter 11 bankruptcy. See BRACEY, supra note 69, at 100-04. This trend is also not uncommon to for-profit firms in the United Kingdom. Just recently, W.S. Atkins terminated prematurely (by three years) a contract for extensive education services with Southwark schools. See Macalister, supra note 100. 
cess is often defined in varying terms. ${ }^{110}$ Nonetheless, a cursory inquiry into student achievement, parent satisfaction, teacher retention, and profitability is essential to a discussion of the efficacy of for-profit school management."

Student achievement can be examined by considering several factors including self-reports of student attainment of academic goals, external assessment of academic achievement compared to similar schools, anecdotal evidence, and student-teacher ratios. Evaluations of student achievement in Edison schools are mixed. Not surprisingly, the Edison Annual Report portrays positive academic performance among its students. Rather than focus on student achievement (because many Edison schools start with lower student achievement scores than those of district-run schools), Edison emphasizes student improvement. ${ }^{112}$ Based on data from 1995 to 2001, 84 percent of Edison's schools demonstrate positive improvement in student achievement, whereas 16 percent of their schools demonstrate a decline in student performance. ${ }^{113}$ On criterionreferenced tests (where student achievement is measured according to mastery of specific standards), Edison reports an average 4 percent annual gain in percent proficient. ${ }^{114}$ On norm-referenced tests (where student achievement is measured against other students and national percentiles are established), Edison schools report an average of 4.4 percentile point gains for each year its schools have been in operation. ${ }^{115}$

Edison's reports, however, have been criticized for failing to compare its students to similar students in non-Edison schools. ${ }^{116}$ Consequently, the American Federation of Teachers (AFT) has sponsored research comparing the efficacy of student achievement in Edison schools with that of students in similar schools.

110. For example, some institutions measure educational success by looking at career preparedness, while others look purely at the academic achievement of its students.

111. This section looks at student achievement, parent satisfaction, and teacher retention based only on the experience of Edison schools. Since Edison has had the longest and most stable history in the for-profit school management industry, data collected by Edison and about Edison (by external researchers) is likely to yield the most instructive projections.

112. Edison Annual Report, supra note 62, at 14-22.

113. Id. at 17 .

114. Id. at 18

115. Id.

116. F. Howard Nelson \& Nancy Van Meter, Update on Student Achievement for Edison Schools Inc. at i (Jan. 2003) (referencing criticisms raised in a 2002 report by the General Accounting Office), available at http:/www.aft.org/research/edisonschools/Edison2003.pdf (last visited Dec. 30, 2003) [hereinafter Update on Edison]. 
In 2000, researcher F. Howard Nelson wrote, "[students in Edison] schools mostly do as well as or worse than [students in] comparable public schools; occasionally they do better." 17 The most recent AFT research compares Edison student performance on academic year 2000-01 state assessments with performance of students in schools with similar populations. ${ }^{118}$ In the study, the average math and reading score of each Edison school was ranked against that of comparator schools. ${ }^{19}$ The rankings were then converted to a decile scale ranging from 1 , as the lowest, to 10 , as the best. ${ }^{120}$ While the average rank of comparator schools was always a 5.5, Edison's rank, as averaged across all states, was below the 5.5 mark. ${ }^{121}$ First year Edison schools averaged rankings of 3.6 in math and 3.5 in reading. ${ }^{122}$ Edison schools that had been open for at least three years averaged a 4.3 in both math and reading. ${ }^{123}$ While it is likely that organizational stability contributes to student achievement and these rankings will increase with Edison's longevity, there is little suggesting that the Edison option presents a clear advantage to students.

Additionally, class size can be considered as a factor contributing to or obstructing student achievement. The National Center for Education Statistics reports that in 1999 the average Edison class size was twenty-eight pupils, whereas the national average elementary school class size was twenty-four pupils. ${ }^{124}$ While not dispositive, this figure argues against high student achievement. On the whole, these statistics and reports suggest that the academic performance of Edison students is at worst flailing, and at best uncertain.

Anecdotal evidence of school district satisfaction regarding student achievement is another indicator worth considering in measuring success. In 2002, Edison received unflattering attention as many local education agencies publicly reevaluated or cancelled contracts with Edison because of concerns over poor

117. F. Howard Nelson, Trends in Student Achievement for Edison Schools, Inc.: The Emerging Track Record 6 (2000), available at http://www.aft.org/research/edisonproject/ (last visited Dec. 30, 2003).

118. Update on Edison, supra note 116, at i.

119. Id. at ii.

120. Id.

121. Id.

122. Id.

123. Id.

124. Digest of Education Statistics 1999: Tbl. 70, at 80 (National Center for Education Statistics, Washington, D.C.), Report No. NCES 1999-036 (1999). 
student performance. ${ }^{125}$ For example, in Wichita, the local education agency cancelled their contract with Edison after eight years. The local agency determined that Edison was not able to offer better educational services than the district could on their own in light of dismal test scores, declining student enrollment, high teacher turnover, inadequate support for children with special needs, difficulties communicating with Edison executives, and even allegations of cheating. ${ }^{126}$ Additionally that year, the Dallas school board voted to end its contract with Edison after Texas Education Agency ratings of two of its seven schools fell from "acceptable" to "low achieving." 127 In short, the board found that Edison student performance was not sufficiently better to justify the higher per-pupil spending. ${ }^{128}$ Local agencies in Massachusetts, Michigan, and Connecticut found similar reasons to terminate contracts with Edison that year. ${ }^{129}$ During Edison's first four years of operation, contracts for services with thirty out of sixty-four schools were terminated; today, Edison still struggles to keep local education agencies satisfied. ${ }^{130}$

Similarly, parent satisfaction reports in Edison schools are mixed. According to the Edison Annual Report, 85 percent of Edison parents rate their school with an "A" or "B" mark. ${ }^{131}$ As a measure of comparison, the Annual Report cites a Gallup poll of parents of public school students. ${ }^{132}$ The Gallup poll indicates 71 percent of public school parents rate their school with an " $A$ " or " $B$ " mark. ${ }^{133}$ This high rate of satisfaction among public school parents gives pause to consider the validity of claims about the dismal performance of public schools, how satisfaction is measured, and what satisfaction actually reveals about schools and parents. Furthermore, Edison figures its 85 percent satisfaction rate based on only 26,000 parental surveys. ${ }^{134}$ If Edison services over 132,000 students, it seems unlikely that all parents, or even a statistically significant portion of them, participated in the survey. Furthermore, as with school success

125. BRACEY, supra note 69, at 115.

126. Josh Funk, Officials: Edison Did Not Deliver, Wichita Eagle, Dec. 1, 2002, available at http://www.kansas.com/mld/ (last visited Dec. 30, 2003).

127. BraceY, supra note 69 , at 115.

128. Funk, supra note 126.

129. BRACEY, supra note 69 , at 115.

130. Update on Edison, supra note 116, at ii.

131. Edison Annual Report, supra note 62, at 5, 28.

132. Id. at 28.

133. Id.

134. Id. 
measures in general, there are many unrelated variables that can affect a parent's satisfaction estimate.

According to CorpWatch, Edison schools average a 23\% teacher turnover rate, which is twice that for urban public schools nationally. ${ }^{135}$ The Edison Annual Report is reasonably consistent with these figures and indicates that the median teacher turnover rate from 2001 to 2002 was $20 \% .{ }^{136}$ In other words, half of Edison schools had rates higher than $20 \%$ and half had rates that were lower. ${ }^{137}$ Edison partially attributes this high figure to its recent contract with seven schools in the Las Vegas district, which is the fastest growing district in the country with the attendant high teacher turnover rates. Excluding the Las Vegas schools, Edison's median rate of teacher turnover was $18 \%$, still considerably higher than the urban national average. ${ }^{138}$ Curiously though, Edison indicates that $86 \%$ of their teachers rate their "career satisfaction" with an " $A$ " or " $B$ " grade. ${ }^{139}$ How Edison reconciles their low teacher retention rates with high career satisfaction figures is uncertain. In any event, teacher retention and satisfaction measures in Edison schools do not reveal an overwhelmingly strong collective commitment to the communities or goals purported to be served.

Perhaps the clearest measure of success among for-profit school management corporations is the rate of return to shareholders. ${ }^{140}$ On this measure, it is certain-there have not been any for-profit, publicly held education management companies in the United States that have consistently profited. ${ }^{141}$ In the past decade, Edison has lost more than $\$ 233.5$ million. ${ }^{142}$ However, Edison CEO John Chubb continues to promise stockholders that profitability will come with large scale expansion. ${ }^{143}$ Despite the numerous contract cancellations and public

135. See American Federation of Teachers, Student Achievement in Edison Schools: Mixed Results in an Ongoing Enterprise, (Oct. 1, 2000), at http:/www.corpwatch.org/issues/PID (last visited Oct. $24,2003)$. CorpWatch is a watchdog group aimed at "holding corporations accountable." Id.

136. Edison Annual Report, supra note 62, at 31.

137. Id.

138. Id.

139. Id. at 5.

140. See, e.g., Note, The Hazards of Making Public Schooling a Private Business, 112 Harv. L. Rev. 695 (1999).

141. Miner, supra note 36, at 132.

142. Id.

143. See John E. Chubb, Education: The Private Can Be Public, Hoover Dig., 2001, available at http://www-hoover.stanford.edu/publications/ (last visited Jan. 15, 2004); see also Conn, supra note 45 , at 141 . 
criticism over student performance, Edison continues to land new contracts. In 2001 sales were $\$ 375.8$ million and their growth rate was 67.3 percent. ${ }^{144}$ Their net income was $\$ 38.1$ million and their number of employees increased significantly as well. ${ }^{145}$ Enthusiastic about international expansion and the requirements of the No Child Left Behind Act, Edison investors are eager to begin receiving returns. ${ }^{146}$

In the United Kingdom, however, some education management organizations and their investors have enjoyed lucrative returns. ${ }^{147}$ In 2000 alone, W.S. Atkins generated over $\mathfrak{f} 650$ million in profit. ${ }^{148}$ Although much of this profit comes from their consultancy services in health care, transportation, and construction in Europe, the Middle East, and Southeast Asia, Atkins' foray into education services enjoys security absent from for-profit ventures in the United States. ${ }^{149}$ While Nord Anglia was worth a reported $£ 32$ million in 2001, the firm's profits are projected to grow at more than 30 percent in the next few years. ${ }^{150}$ As a growth sector, education is expected, according to financial analyst Capital Strategies, to reach $£ 5$ billion by 2006. ${ }^{151}$ Department for Education and Skills initiatives that encourage privatization coupled with economically secure corporations, suggest that these projections are on target.

In sum, there is little evidence that for-profit school management corporations offer substantially better services than those offered by traditional public providers. Neither is there convincing data to suggest that for-profit providers are able to offer a similar quality of services in a more efficient manner. While forprofit firms may have the efficiency edge in terms of managing materials and back-office functions, there is no short-cut to delivering the service and ensuring that learning takes place. The labor intensive nature of primary and secondary education cuts against any advantages achieved through other efficiency-oriented mechanisms. For-profit firms have had trouble simultaneously delivering highquality services and realizing profitability for shareholders. There are no simple

144. See Hoovers Online Financial Fact Sheet for Edison Schools, Inc., at http:// premium.hoovers.com (last visited Oct. 11, 2003).

145. Id.

146. See Conn, supra note 45, at 141-42.

147. See Burkeman, supra note 73.

148. Id.

149. See id.

150. Mathiason, supra note 77.

151. Id. 
solutions to address the challenges which have troubled these firms and it is doubtful that large-scale expansion will be the panacea to all ills.

\section{Forces that Support Expansion of Trade in Education Services}

Like other public services that have become subject to extensive privatization, deregulation, and international competition, public education is likely to be the next target. ${ }^{152}$ The Global Alliance for Transnational Education and other education industry advocates actively lobby for international expansion of education services. The goal, for these groups, is to relax trade barriers so that foreign markets may be opened to trade in private education services. ${ }^{153}$ Today, international trade in the education industry is taking on new forms, targeting primary and secondary education, and expanding at a rapid pace. The General Agreement on Trade in Services (GATS) plays an instrumental role in promoting trade of this type. ${ }^{154}$

The international rules proposed by the General Agreement on Trade in Services (GATS) provide a structure of periodic negotiations, which operate to promote international trade in services on a continuing basis. ${ }^{155}$ As the first

152. Note also that the European Roundtable of Industrialists, a corporate lobby group, has declared that "the provision of education is a market opportunity and should be treated as such." Competitiveness Working Group, Eur. Round Table, Job Creation And Competitiveness Through Innovation 18 (1998), http://www.ert.be./pf/enf_frame.htm. Although this reference seemed to be directed at higher education, the document consistently emphasized the expansion of entrepreneurship at all levels of education in the EU.

153. See Frase \& O'Sullivan, supra note 108 . The conquest of foreign markets has already become a goal among higher education institutions. See generally Background Note, supra note 37 (highlighting various reasons higher education providers seek to reduce barriers to international trade and enhance the mobility of providers and consumers). In the United States, higher education is the fifth largest service sector export. While most revenues come from the exchange of teachers and students in study abroad programs, significant profits are made by higher education service providers abroad. See Marjorie Griffin Cohen, The World Trade Organisation and Post-Secondary Education: Implications for the Public System (Mar. 7, 2000), at http://www.esib.org/ (last visited Oct. 11, 2003).

154. The European Commission refers to GATS as "first and foremost an instrument for the benefit of business." Trade in Services: MEP briefing, available at http:/gats-info.eu.int/ (last visited Oct. 24, 2003).

155. See GATS, supra note 9, at 1180-81 ("Members shall enter into successive rounds of negotiations, beginning not later than five years from the date of entry into force of the WTO Agreement and periodically thereafter, with a view to achieving a progressively higher level of liberalization. Such negotiations shall be directed to the reduction or elimination of the adverse effects on trade in services of measures as a means of providing effective market access."). 
multilateral agreement on investment, it covers all possible means of supplying a service, including the right to establish a commercial presence on the export market. ${ }^{156}$ Under GATS, all services are included "except those provided under governmental authority on a non-competitive basis." ${ }^{157}$ Further, GATS includes four modes of trade in services: "cross border supply" of a service from one member country to another, "consumption abroad" by citizens of member countries in other member countries, "commercial presence" in the territory of another member country, and finally, "the presence of natural persons" in another member's country. ${ }^{158}$

The principles underlying the GATS Agreement include access to markets, national treatment status, and most favored nation status. ${ }^{159}$ "Market Access" imposes an obligation on the government of a country to allow a transnational provider to establish and operate its business freely. ${ }^{160}$ Specifically, there are no limitations on "movement of capital," the "numbers of service suppliers," the "total value of service transactions," "the total number of services operations" or the "total quality of service output" allowed. ${ }^{161}$ "National treatment" status, another benefit conferred by GATS, permits any foreign investor to be treated at least as favorably as any national service provider. ${ }^{162}$ Thus, any discrimination in favor of national service providers or obstruction of full market access is prohibited by those countries choosing to participate in this agreement (and the World

156. See GATS, supra note 9, at 1169.

157. Notably, the concept of services is very broad. The definition of "services' includes any service in any sector except services supplied in the exercise of governmental authority; 'a service supplied in the exercise of governmental authority' means any service which is supplied neither on a commercial basis, nor in competition with one or more service suppliers." GATS, supra note 9, at 1169.

158. Id.

159. See GATS, supra note 9 , at 1169, 1179-80.

160. See GATS, supra note 9, at 1179-80.

161. Id. This principle requires members to inform foreign suppliers of any limitations on access. Foreign suppliers can then, through their governments (so long as their governments are WTO members), challenge these limitations through the WTO Dispute Settlement Process.

162. GATS, supra note 9, at 1180 . This principle requires member states to inform foreign suppliers about restrictions which place them in a less favorable position than their domestic counterparts. For example, if a U.S. for-profit school management corporation wanted to enter the U.K. market, the corporation must be informed of standards of treatment for U.K. education service providers. If there are disparities between the standards and actual treatment or if the information about the standards is insufficient, the U.S. corporation could seek a remedy through GATS by requesting the United States to initiate the WTO Dispute Settlement Process. 
Trade Organization). Principles of market access and national treatment status apply only when member countries choose to apply them to scheduled commitments. ${ }^{163}$ Most favored nation treatment, on the other hand, is a general obligation which applies to all trade in services. ${ }^{164}$ Thus, a country must extend most favored nation treatment to all members, unless an exemption is obtained for specific services. In short, most favored nation treatment requires participating countries to treat service providers of member nations no less favorably than their own national providers. ${ }^{165}$

The most distinctive features of the GATS are its extremely broad coverage and its flexibility. As written, the far-reaching language covers all sectors and measures of trade in services. ${ }^{166}$ At the same time, member countries have the flexibility to explicitly exclude certain sectors or measures in negotiations. ${ }^{167}$ Aside from general obligations, such as most favored nation treatment, member countries define the extent of their own specific commitments. ${ }^{168}$ In the schedules, commitments and limitations are specified for each of the four modes of trade: cross-border supplies, consumption abroad, commercial presence, and presence of natural persons. ${ }^{169}$

Education services under GATS, and within the WTO, are divided into five sub-sectors: primary, secondary, higher, adult, and other. ${ }^{170}$ On a sector-bysector basis, countries indicate the extent to which foreigners may provide services. ${ }^{171}$ Twenty-four of the $140 \mathrm{WTO}$ members have included commitments for at least four of the five education sectors. ${ }^{172}$ Twenty-nine countries have made

163. See GATS, supra note 9, at 1179-81.

164. See GATS, supra note 9, at 1169 ("With respect to any measure covered by this Agreement, each Member shall accord immediately and unconditionally to services and service suppliers of any other Member treatment no less favourable than that it accords to like services and service suppliers of any other country.").

165. See id.

166. Except for "services supplied in the exercise of governmental authority." GATS, supra note 9 , at 1169.

167. See Structure of the GATS, at http://www.wto.org/ (last visited Jan. 20, 2004).

168. See GATS, supra note 9, at 1181.

169. Id.

170. WTO website, at http://www.wto.org/ (last visited Oct. 24, 2003).

171. GATS, supra note 9, at 1181. See Table I: Liberalization Commitments in Each of the Five Education Subsectors, at http://www.right-to-education.org/content/strategy/table_1.html (last visited Oct. 24, 2003) [hereinafter Table I].

172. Table I, supra note 171; see Larsen et al., supra note 6, at 15. 
market access commitments for both primary and secondary education sectors. ${ }^{173}$ The data indicates that the application of GATS to education services is broader in industrialized and transition countries than in developing countries. ${ }^{174}$ The United States, however, is an exception since the only sub-sectors that have been opened are "adult education" and "other education services." 75 Some governments have already opened up all sub-sectors of private education without restrictions. In the European Community, for example, there are no barriers on Market Access or limitations on the National Treatment provision for all sub-sectors except "other education." 176 Thus, U.K. primary and secondary education markets appear to already be open to foreign suppliers. ${ }^{177}$

The GATS definition of services suggests that in order for a country's public education system to be excluded from its scope, a system must be "financed and administered completely by the State" and must be free from "commercial purposes." 178 Data published by the Organization for Economic Cooperation and Development (OECD) suggests that private sources comprise a significant proportion of the funding for systems of education..$^{79}$ On average, OECD countries accept 12 percent of their education funding from private sources. ${ }^{180}$ Since most countries employ mixed public/private systems of education, there are very few, if any, education systems which meet these rigid criteria defining the exception. ${ }^{181}$

173. See Table I, supra note 171. These countries include: Albania, Austria, Bulgaria, China, Costa Rica, Czech Republic, Estonia, the European Community, Georgia, Hungary, Jamaica, Japan, Kyrgyz Republic, Latvia, Lesotho, Liechtenstein, Lithuania, Mexico, Moldova, New Zealand, Norway, Panama, Poland, Sierra Leone, Slovak Republic, Switzerland, Taiwan, Thailand, and Turkey.

174. See Table I, supra note 171.

175. See id.

176. See id.

177. Id.

178. GATS, supra note 9 , at 1169.

179. On the low end are countries such as Norway, Sweden, and Portugal, which receive less than 3 percent of their education funding from private sources. At the other end are countries such as Chile, China, and Korea, which accept more than 43 percent of their education funding from private sources. OECD, Education at a Glance 2002-Chapter B: Financial and Human Resources Invested in Education, Tbl. B4.1 (1995, 1999) (providing relative proportions of public and private expenditure on educational institutions for all levels of education), at http:// www.oecd.org/ (last visited Oct. 21, 2003).

180. Id.

181. See Glenn Rikowski, Schools: The Great GATS Buy, Information for Social Change 3-4 (considering and discounting the argument that public funding immunizes a privately provided service from GATS rules), available at http://www.ieps.org.uk.cwc.net/ (last visited Oct. 24, 2003). 
Additionally, if countries impose a fee for compulsory education, then those education services are not provided completely by the state. ${ }^{182}$ Attempting to clarify this language, the WTO suggests the exemption is intended to cover any public services provided at non-market conditions. ${ }^{183}$ But again, this appears to allow only a very narrow exception. For example, if a government provides free compulsory education, but also permits "competition" with for-profit schools, education is supplied "in competition with one or more services suppliers." ${ }^{84}$ Thus, the exception is insufficient to insulate public education from the forces of international trade. ${ }^{185}$ Consequently, national systems of public education (in almost all cases) will not be considered exempt from GATS provisions, unless explicitly stated. In short, once a country commits to open trade in primary and secondary sub-sectors, public education providers will meet with an even broader array of private education service competitors.

Additionally, GATS discourages participating nations from enacting legislation or regulations which impede commitments to trade in services. While the preamble recognizes, "the right of members to regulate, and to introduce new regulations, on the supply of services within their territories in order to meet national policy objectives," 186 there appear to be provisions which limit a member country's right to enact regulations which may be considered barriers to trade in services. ${ }^{187}$ If regulations are determined to be discriminatory towards foreign suppliers, the regulations are likely to be characterized as non-tariff barriers, and in contravention of the Agreement. Further, GATS discourages governmental action which awards subsidies to national establishments. ${ }^{188}$ Thus, the

182. See Right to Education, Whither Education?: Human Rights Law Versus Trade Law, available at http://www.right-to-education.org/ (last visited Oct. 24, 2003).

183. See WTO website, at http://www.tsdb.wto.org/ (last visited Oct. 24, 2003).

184. See Right to Education, supra note 182, at 3.

185. See id.

186. GATS, supra note 9, at 1168.

187. For example, "in sectors in which a member has taken specific commitments ... the member shall not apply licensing and qualification requirements and technical standards that nullify or impair such specific commitments." GATS, supra note 9, at 1173. Or, "in sectors where marketaccess commitments are undertaken... a Member shall not maintain or adopt... measures which restrict or require specific types of legal entity or joint venture through which a service supplier may supply a service ... [or] limitations on the participation of foreign capital." GATS, supra note 9 , at 1179-80.

188. See GATS, supra note 9, at 1179 ("Members recognize that, in certain circumstances, subsidies may have distortive effects on trade in services. Members shall enter into negotiations with a view to developing the necessary multilateral disciplines to avoid such trade-distortive effects."). 
choice to open primary and secondary sectors to trade in services could greatly impact a government's ability to aid a national system of education.

Since the GATS Agreement contains such sweeping language in some instances and such narrow language in others, a country's commitments could have dramatic implications for trade in education services unless language is clarified and exclusions are made. For instance, the exception to the definition of services could be read so narrowly as to render any exception meaningless, thereby opening public education to unintended competition. Or, the provision discouraging national subsidies could be read broadly to limit a country's right to favor its own education system. Thus, it is critical for participating countries to take affirmative steps to limit the scope and application of their commitments. Further, this requires countries to define and outline goals for public education and parameters for private infiltration. Failure to do so could allow GATS to accelerate and spread the process of privatization, which is already occurring in education in the United Kingdom.

Despite the failure of the Seattle Ministerial Meeting in 1999, which was intended to strengthen the GATS commitment, the WTO's Council for Trade in Services has worked to continue negotiations. ${ }^{189}$ The current round of GATS discussions began in February 2002 at the WTO headquarters in Geneva. ${ }^{190}$ Only four WTO members (Australia, Japan, New Zealand, and the United States) have, to date, submitted proposals on the role of GATS in promoting the liberalization of education services. ${ }^{191}$ Each proposal seeks the removal of obstacles to higher education, but only the Australian and New Zealand proposals apply to education at all levels. ${ }^{192}$ The U.S. proposal explicitly excludes primary and secondary education sectors and is careful to note that subsidies for higher

189. Rikowski, supra note 181 , at 2.

190. Id.

191. Thomas Fuller, Education Exporters Take Case to WTO, International Herald Tribune, Special Report, 15 (Feb. 18, 2003), available at http:/www.globalpolicy.org (last visited Jan. 15, 2004).

192. Communication from Australia, Negotiating Proposal for Education Services, Council for Trade in Services Special Session, WTO S/CSS/W/1 10 (Oct. 1, 2001), at www.wto.org/; Communication from New Zealand, Negotiating Proposal for Education Services, Council for Trade in Services Special Session, WTO S/CSS/W/93 (June 26, 2001) at www.wto.org/; Communication from the United States, Higher (Tertiary) Education, Adult Education, and Training, Council for Trade in Services Special Session, WTO S/CSS/W/23 (Dec. 18, 2000), at www.wto.org/. 
education will not be made equally available to foreign providers. ${ }^{193}$ Japan's proposal emphasizes the importance of continued liberalization of trade of education services, but also expresses concern with international equivalence, quality, and consumer (student) protection. ${ }^{194}$ In November 2001, the Doha Development Agenda was initiated to hasten negotiations and an agreement target date was set for $2005 .{ }^{195}$

\section{Global Trade in For-Profit Management Services: Implications for Public Education in Developing Countries}

The expansion of trade in primary and secondary education services, particularly the expansion of markets for for-profit management corporations, has implications for both industrialized and developing nations. Significantly, even GATS guidelines give notice of the challenges developing countries face to balance sensitivity to public education policy with the expansion of trade. ${ }^{196}$ This section addresses some of those implications, but also sets forth reasons why countries should proceed with caution when choosing to open primary and secondary education sectors to trade in services and allowing for-profit education services to infiltrate these markets.

The primary reason countries should be cautious about opening their borders to for-profit school management is based on the experience of these organizations. Currently, there is no clear evidence that for-profit management can

193. Communication from the United States, Higher (Tertiary) Education, Adult Education and Training, Council for Trade in Services Special Session, WTO S/CSS/W/23 (Dec. 18, 2000) at www.wto.org/.

194. Communication from Japan, Negotiating Proposal on Education Services, Council for Trade in Services Special Session, WTO S/CSS/W/137 (Mar. 15, 2002) at www.wto.org/.

195. See The Doha Declaration Explained, at http://www.wto.org/ (last visited Mar. 18, 2004) (giving an unofficial explanation of the declaration's mandates).

196. GATS, supra note 9, art. XIX para. 2, at 118:

The process of liberalization shall take place with due respect for national policy objectives and the level of development of individual Members, both overall and in individual sectors. There shall be appropriate flexibility for individual developing country Members for opening fewer sectors, liberalizing fewer types of transactions, progressively extending market access in line with their development situation and, when making access to their markets available to foreign service suppliers, attaching to such access conditions aimed at achieving the objectives referred to in Article IV. 
attain higher levels of student achievement or greater efficiency than their traditional counterparts. Simply put, if there is negligible gain in contracting with for-profit providers, there is hardly reason to turn away from protecting and supporting the established public system. This inability to attain a markedly different result from the status quo is, at least in part, attributable to an instability which has characterized for-profit organizations since entering the market. Frequent executive turnover, bankruptcy, and terminated contracts have challenged even the longest-running and the most financially secure corporations. Until for-profit education management can demonstrate consistency in attaining their goals, education agencies in developing countries should be reluctant to embrace these services as an alternative to an existing system.

In many countries, however, where the existing education system is extremely weak, even negligible gain is improvement. In these cases, there may be viable reasons to consider opening the trade doors to for-profit school management providers. But even in these situations, there are reasons to be wary. The nature of the private corporation is to maximize profits for the shareholders, who provide the capital to support the organization. ${ }^{197}$ Since profits depend on the extent to which revenues exceed costs, there is inherent tension between shareholders and customers (i.e. local education agencies, and by extension students). ${ }^{198}$ The corporation and its shareholders are the exclusive beneficiaries of the directors' duties of care, loyalty and good faith. ${ }^{199}$ Consequently, when the local education agency and the corporation contract for services, the bargaining power of parents, community members, teachers, and students is subsumed. ${ }^{200}$ Those to whom the school should be most accountable are, in fact, those who end up having little control. While the local agency can terminate their contract with the for-profit firm, this decision has many negative implications and frequently results in even greater turmoil for struggling districts. Thus, countries seeking to expand opportunities for private education service providers must consider the ramifications of an education system driven by profitability for shareholders who have little interest in allowing local control.

197. See Conn, supra note 45, at 129, 132-34 (discussing the shareholder wealth maximizing principle and general fiduciary duties of corporations).

198. See Chris Pipho, The Selling of Public Education, 79 Ph Delta Kappan 101 (1997), available at http://www.pdkintl.org/kappan/kpip9710.htm.

199. See Conn, supra note 51, at 256.

200. Conn, supra note 45, at 133. 
In addition to concern about retaining local bargaining power in directing the goals of an education system, the drive to minimize costs is likely to bring even more challenges. To realize profitability, for-profit management firms must operate on a large scale and standardize their mode of delivery of services. ${ }^{201}$ For example, many companies employ a model curriculum that is implemented at every school. ${ }^{202}$ While this may result in cost savings, it may not be the best way to serve students with a diversity of backgrounds and needs. Teacher and community responsiveness to student needs is a critical force in not only directing learning and measuring knowledge, but also in instilling community values and preparing students to participate in their labor market. Education management organizations have struggled with the labor-intensive nature of schooling. It is likely that the needs of students and communities in developing countries will exacerbate this challenge. While any education is obviously better than none, the underlying values of education management organizations are often incongruent with providing a public good for the community. The profit-driven underpinnings of education management organizations will require communities to rethink the role of public education in society. Privatization of education in this manner suggests that "education is a commodity or a readily mechanized process of inputs and outputs rather than a vehicle for deliberation, debate and decisionmaking." 203 When this occurs, education becomes less about social enterprise and more about private gain. ${ }^{204}$

Further, developing countries have reason to be concerned about the potential threats posed to cultural values and national traditions when for-profit management providers enter the market. ${ }^{205}$ For example, cultural and linguistic diversity is threatened when management companies, such as the Nord Anglia international schools, import curricula from host countries. ${ }^{206}$ Trade in higher education presents another example: today, many universities in Europe and Asia teach only in English. ${ }^{207}$ If education management organizations, in their expansion to world markets, take the same course as higher education trans-

201. Conn, supra note 51, at 246.

202. Conn, supra note 45 , at 145.

203. Note, supra note 140 , at 708.

204. Id. at 709 .

205. Larsen et al., supra note 6 , at 22.

206. See Alex Nunn \& Jess Worth, GATS and Education, Campaign for Free Education, at http:// homepage.tinet.ie/ (last visited Mar.15, 2004).

207. Id. 
national providers, primary and secondary education will become more business-focused and targeted toward creating global consumers. While this offers some advantages, it also creates a homogeneous workforce and may undermine students' ability to critically problem-solve for their own communities. The lure of a "one-stop" education-shop may be appealing to communities with failing education systems, but the mores that may be transmitted in the provision of such services are likely to entrench external market values.

Countries that open trade in primary and secondary education services must also consider an altered role for the state in overseeing the delivery of these services. As it has with other public services that have been privatized and opened to international trade, the state is likely to take a more regulatory role to ensure the service is delivered as needed and in alignment with state and international law. To effectuate these goals, a system of carefully crafted regulations and vigilant review is required. Some fear, however, that once private options are available, governments will be less inclined to accept an enhanced regulatory function and to provide public assistance to service agencies. ${ }^{208}$ Further, while the emergence of for-profit management corporations may relieve a government of some of the burden for ensuring free, compulsory education is offered, it may also have the effect of passing the cost of the education on to the consumers, particularly if GATS rules limit government subsidies to public education services. ${ }^{209}$ Consequently, those students and families who can afford the forprofit education will benefit, while those who cannot will remain in the underfunded public systems. ${ }^{210}$ If this occurs, it will likely broaden the chasm between the haves and have-nots. Governments committed to equal access education will need to take affirmative steps to prevent such a trend.

The proliferation of for-profit education management organizations and the concomitant impact of this expansion have had and will continue to have farreaching implications for those in developed and developing countries. At bottom is a complex and difficult choice about what methods of delivery best serve the public interest. In the interim, countries must take affirmative steps to preserve their right to wrestle with such choices.

208. Kirstin Larson, Commercialism in Schools, ERIC Digest, No. 158, ED465194 (May 2002), at http://www.ericfacility.net/ericdigests/ed465194.html.

209. Nunn \& Worth, supra note 206.

210. Id. 


\section{Looking for something in particular?}

Aesthetic Experience versus Musical Practice Approaches to Jazz Improvization Instruction Bankers' Perspectives on Internet

Banking Bessie Head and the Politics of Narrative Black Women, Politics, Nationalism, and Community in London British Cinema Caribbean Popular Culture in Canada Censorship in Israel Community Political Order Consumer Behavior in Electronic Markets Content in American Jewish Poetry James Joyce's 'A Painful Case' and the Modern Press Defining and Establishing the Boundaries of Cyberliberty Important Design Features in Websites Ethical Practice in Music Education $\quad$ Fact and Fiction in God's Bits of Wood False Memory Syndrome Feminist Politics of Sexual Difference Folklore Studies, Cultural Studies, and History Gender, Faith, and Responses to HIV/AIDS in Africa Gender, Genocide, and Jewish Memory Genealogy of Evil Incarnate Genetic Science and Ethics German Soldiers and the Holocaust $\bullet$ Ghanaian Fiction $\bullet$ Global Governance Hitler's Reichstag Speech of $1939 \quad$ Homophobia and Gay Rights in Jamaica - Men in Biblical Feminist Scholarship - Music Education as Critical Practice Nineteenth-Century Warsaw Poetics of African Art $\bullet$ Racial Conciliation in Negritude Literature Re-creating and Re-imagining Folk Performing Arts in Contemporary Japan Silent Films Sexual Harassment The Unsuly Woman' in Nineteenth-Century Trinidad Carnival The Effect of Download Time on Consumer Attitude $\quad$ The Future of African Literature and Scholarship The Holocaust According to its Anthologists - The Logic of the Sexual Relation The Political Origins of the New Constitutionalism $\bullet$ The Politics of Ezra Pound Third-Wave Feminist Philosophy $\bullet$ Trauma and Gender in Tender is the Night $\bullet$ Victorian Art History White Writing After Apartheid $\$$ Women,War, and Peace in Jewish and Middle East Contexts

Articles by today's best known scholars on hundreds of fascinating and timely topics are available at your fingertips from the Indiana University Press Journals Division's Online Document Delivery Service. Information is just a click away.

\section{http://iupjournals.org}

